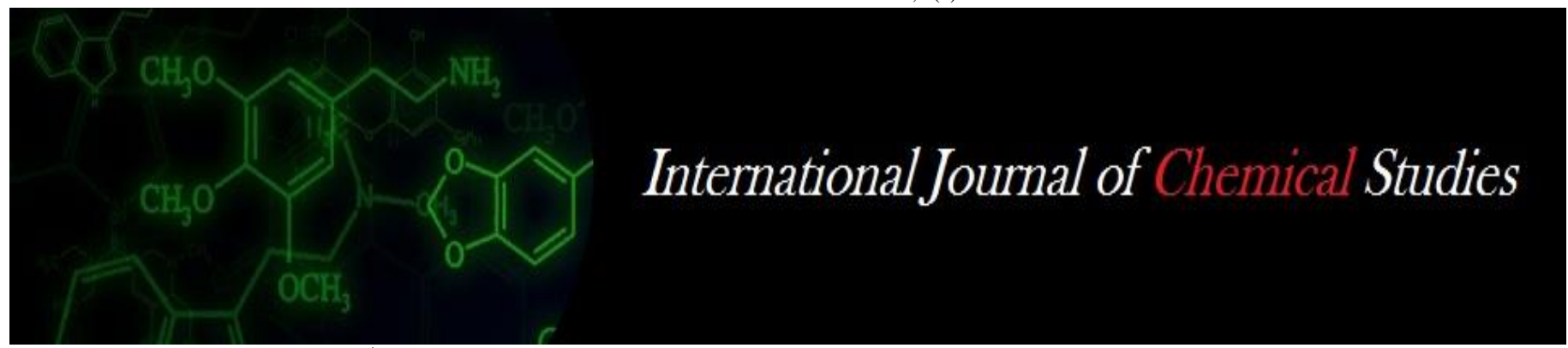

P-ISSN: 2349-8528

E-ISSN: 2321-4902

www.chemijournal.com

IJCS 2020; 8(2): 1354-1359

(C) 2020 IJCS

Received: 01-01-2020

Accepted: 05-02-2020

Yuvaraj Sopan Balgude Agricultural Research Station, Lonavala, Tal. Maval, Pune, Maharashtra, India

Anil Parshuram Gaikwad Agricultural Research Station, Lonavala, Tal. Maval, Pune,

Maharashtra, India

Anil M Tirmali

Agricultural Research Station, Lonavala, Tal. Maval, Pune,

Maharashtra, India
Corresponding Author: Yuvaraj Sopan Balgude Agricultural Research Station, Lonavala, Tal. Maval, Pune, Maharashtra, India

\section{Integrated management of sheath rot and brown spot of paddy}

\section{Yuvaraj Sopan Balgude, Anil Parshuram Gaikwad and Anil M Tirmali}

DOI: https://doi.org/10.22271/chemi.2020.v8.i2u.8950

\begin{abstract}
The trial was conducted subsequently during three years for development of integrated disease management module in rice with main plot treatments consisting of seed treatment (ST) of benomyl $(0.3 \%)$ followed by Pseudomonas fluorescens $(0.5 \%)$ and cultural practices (CP) like soil application of rice husk ash (RHA) at sowing on raised beds $\left(1 \mathrm{~kg} \mathrm{~m}^{-2}\right)+$ soil application of rice straw (RS) @ 2 tones $\mathrm{ha}^{-1}$ at transplanting and no ST and CP together with eight fungicide treatments including absolute control as subplot treatments. The pooled results revealed that the lowest sheath rot $(25.02 \%)$ and brown spot (11.11) diseases with highest disease reduction of 63.05 and 79.69 per cent, respectively were recorded in the treatment combination of $\mathrm{ST}+\mathrm{CP}$ with three sprays of propiconazole $(0.1 \%)$ at 15 days interval starting first spray at disease appearance. Thereby, this treatment produced highest grain (35.57 $\mathrm{q} / \mathrm{ha}$ ) and straw (40.09 $\mathrm{q} / \mathrm{ha}$ ) yield with substantial increase in the grain $(101.23 \%)$ and straw $(93.10 \%)$ yields as well as gave higher monitory benefits such as total monetary returns of Rs. $58048.85 \mathrm{ha}^{-1}$, net profit of Rs. $30905.85 \mathrm{ha}^{-1}$, and B : C ratio of 2.14. This was followed by ST + CP with sprays of bitertanol $(0.25 \%)$, carbendazim $(0.1 \%)$ and tricyclazole $(0.10 \%)$.
\end{abstract}

Keywords: IDM, paddy, brown spot, sheath rot

\section{Introduction}

Rice (Oryza sativa L.) is the most important staple food grain of humid and sub-humid Asia. The productivity of rice is less $(1.8 \mathrm{t} / \mathrm{ha})$ in Maharashtra as compared to India $(2.41 \mathrm{t} / \mathrm{ha})$ [Anonymous, 2014] ${ }^{[3]}$. The major constraints for low productivity are diseases occurring on this crop. More than 70 diseases are caused by fungi, bacteria, viruses or nematodes on rice. Among the several diseases infecting rice, the severe diseases infecting rice in Maharashtra are sheath rot(Sarocladium oryzae $=$ Acroclinium oryzae) and brown spot Bipolaris oryzae (Cochliobolus miyabeanus) which cause about 30-40 per cent loss in paddy yield depending upon the location, variety infected and severity of diseases.

Sustainable agriculture depends on the use of chemical fungicides, pesticides, herbicides and fertilizers. Repeated use of these chemicals is causing severe concern from the health and environmental point of view. In view of these, the development of IDM based control method of diseases is now viewed not only as an eco-friendly but also sustainable agriculture.

Earlier, it is reported that the rice disease pathogens have been reduced in intensity by silicon (Si) application in rice due to increased resistance (Datnoff et al., 1992 and 2001; Rodrigue et al., 2003 and 2004 and Rodrigue and Datnoff, 2005) ${ }^{[10,19,20]}$. Hence, soils known to be low in plant-available silicon should be amended with calcium silicate slag or other silica sources. In addition, application of the plant growth promoting rhizobacteria (Pseudomonas fluorescens) as seed treatment, broadcasting and foliar spray significantly performed the best results in reduction of six-important diseases (bacterial leaf blight, blast, brown spot, narrow brown spot, sheath blight and dirty panicle caused by Xanthomonas oryzae pv. oryzae, Pyricularia grisea, Helminthosporium oryzae, Cercospora oryzae, Rhizoctonia solani; and complex pathogens including $C$. oryzae, Curvularia lunata, H. oryzae, Fusarium semitectum, Alternaria padwickii, and Sarocladium oryzae, respectively) and increased yield with 52.1 per cent in rice (Prathuangwong et al., 2012) ${ }^{[17]}$.

Hence, looking to the severity of diseases, their economic importance and need of the rice growers, it was very necessary to manage these diseases by integration of all available disease management practices. Therefore, the field trials were conducted by integration of cultural, 
biological and chemical methods for management of brown spot and sheath rot of rice.

\section{Materials and Methods}

A field experiment was conducted at Agricultural Research Station, Lonavala, Tal.-Maval, Dist.-Pune (MS) for consecutive three years during the kharif seasons of 2009, 2010 and 2011. The experimental design was a split-plot with three replications. Main plot treatments consisted of seed treatment (ST) with benomyl (0.3\%) followed by Pseudomonas fluorescens (0.5\%) and cultural practices (CP) like soil application of rice husk ash (RHA) at sowing on raised beds $\left(1 \mathrm{~kg} \mathrm{~m}^{-2}\right)+$ soil application of rice straw $(\mathrm{RS}) @$ 2 tones $\mathrm{ha}^{-1}$ at transplanting and no ST + CP. The subplots included eight fungicide treatments viz., carbendazim $(0.1 \%)$, propiconazole $(0.1 \%)$, bitertanol $(0.25 \%)$, tricyclazole $(0.1 \%)$, iprobenphos $(0.25 \%)$, Kasugamycin $(0.25 \%)$ and alternate sprays with mancozeb $(0.25 \%)$ followed by benomyl $(0.1 \%)$ and copper oxychloride $(0.25 \%)$ including absolute control.

Subplots $(3.0 \times 1.95 \mathrm{~m})$ of each of the treatment consisted of 13 rows of $3.0 \mathrm{~m}$ long at $0.20 \mathrm{~m}$ distance with $0.15 \mathrm{~m}$ plant to plant spacing. The fungicide and bioagent treated seeds of EK 70 , a highly susceptible variety of rice, were sown on the raised beds mixed with the rice husk ash during the last week of June while, the transplanting of seedlings was carried out in the last week of July during every year of experimentation. The rice straw was added before transplanting in the puddled field. The crop was fertilized with 50N:50P:50K as basal dose and top dressed with $50 \mathrm{~N}$ one month after transplanting. The first spray of fungicides was taken immediately after appearance of disease and was followed by two sprays at 15 days interval thereafter. The observations on diseases were recorded by following 0-9 SES scale as per IRRI, Philippines (Anonymous, 2013) and then converting into per cent disease intensity by using the formula.

Sum of the scores X 100

Per cent disease intensity $=$--
Number of observations $X$ highest rating i.e. 9

The data on the grain and straw yields were recorded in net plot as described by Seebold et al., $2004^{[22]}$ and tillers within the plot were cut and harvested in order to determine the yield.

\section{Results}

The pooled data (Tables 1 to 4 ) of all diseases under study indicate that the treatment differences due to ST $+\mathrm{CP}$ and fungicides as well as their interactions were statistically significant.

\section{Sheath rot}

Three years pooled data of sheath rot depicted in Table 1 indicate that the ST + CP had significantly lowest incidence $(73.63 \%)$ and intensity $(33.01 \%)$ of sheath rot and thereby showed highest disease reduction of 51.25 per cent. The treatment with fungicide bitertanol $(0.25 \%)$ recorded least incidence $(66.68 \%)$ and intensity $(23.00 \%)$ and thus maximum disease control of 66.04 per cent. However, it was at par with carbendazim $(0.1 \%)$ and propiconazole $(0.1 \%)$ in respect of intensity, which showed 60.81 and 56.60 per cent disease reduction over control, respectively. Thereafter, among interactions, the lowest incidence and intensity of 61.39 and 18.22 per cent, respectively with highest disease reduction of 73.09 per cent were recorded in the treatment combination of ST + CP with sprays of bitertanol $(0.25 \%)$. Whereas, it was at par with $\mathrm{ST}+\mathrm{CP}$ with spray of carbendazim $(0.1 \%)$ that had 22.29 per cent sheath rot severity with 67.08 per cent disease reduction. This was followed by ST + CP with sprays of propiconazole $(0.1 \%)$ where disease intensity of 25.02 per cent with 63.05 per cent control was noticed.

\section{Brown spot}

Three years' pooled observations on brown spot disease given in Table 2 indicate that the ST $+\mathrm{CP}$ had significantly lowest incidence $(48.24 \%)$ and intensity $(22.48 \%)$ of brown spot and hence showed 58.91 per cent decrease in disease as compared to no ST and CP. As regard to bio-efficacy of fungicides, propiconazole $(0.1 \%)$ recorded significantly least incidence of 41.58 and intensity of 14.75 per cent and thereby highest disease control of 73.04 per cent. However, as regards severity, propiconazole was on par with bitertanol $(0.25 \%)$ that showed 19.16 per cent brown spot with 64.98 per cent disease reduction over control. The interaction between ST + $\mathrm{CP}$ with sprays of propiconazole $(0.1 \%)$ had least disease incidence $(36.03 \%)$ and severity $(11.11 \%)$ and highest brown spot disease control of 79.69 per cent over control. This was followed by ST + CP with sprays of bitertanol $(0.25 \%)$, wherein 72.39 per cent disease control was noticed.

\section{Grain and straw yield}

Three years pooled observations presented in Table 3 illustrate that the ST + CP yielded significantly highest grain (29.90 $\left.\mathrm{q} \mathrm{ha}^{-1}\right)$ and straw (32.14 q ha-1) yield with 66.94 and 54.80 per cent increase in respective yields. Similarly, significantly highest grain (33.69 $\left.\mathrm{q} \mathrm{ha}^{-1}\right)$ and straw (37.85 q $\mathrm{ha}^{-1}$ ) yields with 90.57 and 82.28 per cent increase in grain and straw yield, respectively were noticed in propiconazole $(0.1 \%)$. Further, propiconazole was followed by carbendazim $(0.1 \%)$ and bitertanol $(0.25 \%)$ those recorded 31.73 and 29.76 $\mathrm{q}$ grain as well as 35.32 and $32.71 \mathrm{q}$ straw yields $\mathrm{ha}^{-1}$ thus, 79.50 and 68.36 and 70.10 and 57.52 per cent increase in grain and straw yields over control, respectively. The treatment combination of $\mathrm{ST}+\mathrm{CP}$ with sprays of propiconazole $(0.1 \%)$ yielded significantly highest grain (35.57 $\left.\mathrm{q} \mathrm{ha}^{-1}\right)$ and straw (40.10 $\left.\mathrm{q} \mathrm{ha}^{-1}\right)$ yield thereby, substantial increase in the grain (101.23\%) and straw $(93.10 \%)$ yields over control. However, it was at par with ST $+\mathrm{CP}$ with sprays of carbendazim $(0.1 \%)$ wherein, 33.61 and $37.37 \mathrm{q}$ grain and straw yields $\mathrm{ha}^{-1}$ were obtained with 90.14 and 79.98 per cent increase in grain and straw yields, respectively.

\section{Economics of IDM in paddy}

The data regarding monetary returns and $\mathrm{B}$ : $\mathrm{C}$ ratio presented in Table 4 reveal that ST $+\mathrm{CP}$ gave significantly highest total monetary returns of Rs. $46891.47 \mathrm{ha}^{-1}$, net profit of Rs. 19106.85 $\mathrm{ha}^{-1}$, additional monetary returns of Rs. 19747.57 $\mathrm{ha}^{-1}$ and B: C ratio of 1.69 as against no ST and CP where these parameters were Rs. $39730.66 \mathrm{ha}^{-1}$, Rs. $13940.04 \mathrm{ha}^{-1}$, Rs. $12586.76 \mathrm{ha}^{-1}$ and 1.54 , respectively. Similarly, significantly highest monetary returns (Rs. $53650.13 \mathrm{ha}^{-1}$ ), net profit (Rs. $27504.13 \mathrm{ha}^{-1}$ ), additional monetary returns (Rs. $26506.23 \mathrm{ha}^{-1}$ ) and $\mathrm{B}$ : C ratio (2.05) were noticed in propiconazole $(0.1 \%)$. This was followed by carbendazim $(0.1 \%)$, tricyclazole $(0.1 \%)$, Kasugamycin $(0.2 \%)$ and alternate sprays, which showed B: C ratios of 1.98, 1.66, 1.54 and 1.52 , respectively. Further, the treatment combination of $\mathrm{ST}+\mathrm{CP}$ with sprays of propiconazole $(0.1 \%)$ gave 
significantly highest monetary returns (Rs. 58048.85 ha $^{-1}$ ), net profit (Rs. $30905.85 \mathrm{ha}^{-1}$ ), additional monetary returns (Rs. $30904.94 \mathrm{ha}^{-1}$ ) and B: C ratio (2.14). This was followed by ST $+\mathrm{CP}$ with sprays of carbendazim, tricyclazole (0.10\%), alternate sprays and Kasugamycin $(0.20 \%)$ wherein, B: C ratios of $2.05,1.73,1.60$ and 1.60 were recorded, respectively.

\section{Discussion}

The seed treatment with benomyl and Pseudomonas fluorescens + cultural practices reduced the severity of sheath rot and brown spot of paddy to a considerable extent.

Among the fungicides, propiconazole $(0.1 \%)$ recorded significantly least incidence and intensity and thereby highest disease control of brown spot while, it was on par with carbendazim $(0.1 \%)$ and bitertanol $(0.25 \%)$. However, the fungicides, bitertanol were found to be more effective for management of sheath rot and was followed by propiconazole. Das and Nayak (1997) ${ }^{[6]}$ and Nagrale et al. (2013) ${ }^{[15]}$ recorded significant reduction in sheath rot due to sprays of carbendazim at 0.1 per cent. The findings are also in agreement with the reports of Dodan and Ram Singh (1996) [11], Venkateswarlu and Venkateswarlu (2004) [25] and Venkateswarlu et al. (2004) ${ }^{[25]}$ who noticed that carbendazim and propiconazole at 0.1 per cent each were the most effective fungicides for reducing sheath rot incidence in paddy. As regards brown spot, the results are in conformity with the findings of Sunder et al. (2005) ${ }^{[23]}$ wherein they also reported best control of brown spot of rice by propiconazole $(78.7 \%)$.

The interaction of ST + CP with sprays of propiconazole $(0.1 \%)$ had significantly brown spot severity with highest reduction of these diseases however, this treatment combination was at par with $\mathrm{ST}+\mathrm{CP}$ with sprays of carbendazim $(0.1 \%)$.

Thereafter, among interactions, the lowest incidence and intensity of sheath rot with highest disease reduction were recorded in the treatment combination of ST $+\mathrm{CP}$ with sprays of bitertanol $(0.25 \%)$ whereas; it was at par with ST + CP with spray of carbendazim $(0.1 \%)$. This was followed by ST $+\mathrm{CP}$ with sprays of propiconazole $(0.1 \%)$. These findings are in consonance with the work of Bag et al. (2010) ${ }^{[4]}$ who while evaluating new commercially available botanicals, biopesticides and fungicides against sheath rot of rice under West Bengal conditions found that all the treatments including Pseudomonas fluorescens and carbendazim reduced the disease incidence compared to the control plot Prabhu (1989) ${ }^{[16]}$ mentioned that integrated management involving cultural methods, selection of resistant cultivars and chemical treatments reduced the principal diseases of rice viz., brown spot in central Brazil that is in conformity with present findings. The foregoing results are nearly matching with the report of Raja and Saravanan (1993) ${ }^{[18]}$ who developed an integrated diseases management module in paddy consisting of seed treatment with carbendazim (2 g/kg) and Pseudomonas fluorescens (10g/kg seed) and sprays with fungicide carbendazim $(0.05 \%)$ or tricyclazole $(0.08 \%)$ for management of important rice diseases. Datnoff et al. (2001) ${ }^{[1]}$ in their integrated disease management studies, including use of silica and fungicides, indicated that levels of several important diseases of rice viz., blast, brown spot, sheath blight, leaf scald and grain discoloration reduced to a greater extent hence, the number of fungicide applications and rates can be reduced significantly worldwide. Similarly, Datnoff and Rodrigues (2005) ${ }^{[9]}$ also reported that application of silicon in combination with fungicide sprays with propiconazole ( 0.44 liters/ha) greatly reduced the rice diseases viz., leaf blast, neck blast, brown spot, grain discoloration, leaf scald and sheath blight. In addition, Rodrigues and Datnoff (2005) [9] noticed that the element silicon ( $\mathrm{Si}$ ) effectively managed the rice diseases such as blast, brown spot and sheath blight. Further, Lore et al. (2007) ${ }^{[13]}$ noticed that fungicide propiconazole @ $0.1 \%$ was the most effective against rice diseases viz., sheath blight, sheath rot, brown spot and grain discoloration and was followed by carbendazim @ $0.1 \%$, which is in agreement with the present studies. Besides, Prathuangwong et al. (2012) [17] noticed the most effectiveness of plant growth promoting rhizobacteria Pseudomonas fluorescens SP007s as seed treatment, broadcasting, and foliar spray for suppression of the incidence of various rice diseases like bacterial leaf blight, blast, brown spot, narrow brown spot, sheath blight and dirty panicle.

The data regarding yield and monitory benefits indicated that the $\mathrm{ST}+\mathrm{CP}$ yielded significantly highest grain and straw yields with considerable increase in yields, total monetary returns and B: C ratio. Similarly, significantly highest grain and straw yields as well as total monetary returns and B : C ratio were noticed in propiconazole $(0.1 \%)$ that was followed by carbendazim $(0.1 \%)$, tricyclazole $(0.1 \%)$, Kasugamycin $(0.2 \%)$ and alternate sprays. Datnoff and Rodrigues (2005) ${ }^{[9]}$ reported that application of silicon in combination with fungicide sprays of propiconazole greatly reduced the rice diseases and increased the grain yield to great extent that is matching with the present findings. The results are also in agreement with the work of Hossain and Kulkarni (2001) and Sunder et al. (2005) ${ }^{[23]}$ who recorded propiconazole as the best fungicide in managing the rice diseases and getting higher yields. Further, propiconazole was followed by carbendazim $(0.1 \%)$ and bitertanol $(0.25 \%)$ that also recorded increase in grain and straw yields over control. Dodan and Ram Singh (1996) ${ }^{[11]}$ and Venkateswarlu and Venkateswarlu (2004) ${ }^{[25]}$ also noticed that propiconazole and carbendazim were the most effective fungicides for reducing paddy diseases with a corresponding increase in grain and straw yields. Similarly, Das and Nayak (1997) ${ }^{[6]}$, Tirmali et al. (2001) and Nagrale et al. (2013) ${ }^{[15]}$ also noticed carbendazim at 0.1 per cent as highly effective in controlling the rice diseases and significantly increased grain yield.

The treatment combination of ST $+\mathrm{CP}$ with sprays of propiconazole $(0.1 \%)$ yielded significantly highest grain as well as straw yield with more total monetary returns and B: C ratio and thereby substantial increase in respective parameters over control. However, it was at par with ST + CP with sprays of carbendazim $(0.1 \%)$. The findings are in conformity with the report of Bag et al. (2010) ${ }^{[4]}$ wherein they found that integration of botanicals, biopesticides (Pseudomonas fluorescens) and fungicide (carbendazim) reduced the rice disease incidence and increased grain yield compared to the control plot. The results are also in agreement with Alvarez and Datnoff (2001) ${ }^{[1]}$ Datnoff who also noticed the beneficial effects of integrated management including silicon application on disease management and world rice production that have been translated to monetary values using a yield and costprice structure. In addition, Datnoff and Rodrigues (2005) [9] reported that application of silicon in combination with fungicide sprays with propiconazole greatly reduced the rice diseases and increased the grain yield as well as monitory returns to great extent that is in agreement with the present findings. 
Table 1: Influence of seed treatment, cultural practices and fungicides on management of sheath rot of paddy (Three years' pooled results: 2009, 2010 and 2011)

\begin{tabular}{|c|c|c|c|c|c|c|c|c|c|c|c|}
\hline \multirow{4}{*}{$\begin{array}{l}\text { Sr. } \\
\text { No. }\end{array}$} & \multirow{4}{*}{ Fungicides } & \multirow{4}{*}{ Conc. (\%) } & \multicolumn{9}{|c|}{ Per cent sheath rot } \\
\hline & & & \multirow{2}{*}{\multicolumn{3}{|c|}{$\begin{array}{c}\text { Incidence } \\
\text { Weighted pooled means }\end{array}$}} & \multicolumn{6}{|c|}{ Intensity } \\
\hline & & & & & & & oled me & & Red & uction & $(\%)$ \\
\hline & & & M1 & M2 & Mean & M1 & M2 & Mean & M1 & M2 & Mean \\
\hline \multirow{2}{*}{1.} & \multirow{2}{*}{ Carbendazim } & \multirow{2}{*}{0.1} & 66.04 & 74.07 & 70.06 & 22.29 & 30.78 & 26.54 & \multirow{2}{*}{67.08} & \multirow{2}{*}{54.54} & \multirow{2}{*}{60.81} \\
\hline & & & 47.60 & 52.71 & 50.16 & 28.07 & 33.65 & 30.86 & & & \\
\hline \multirow{2}{*}{2.} & \multirow{2}{*}{ Propiconazole } & \multirow{2}{*}{0.1} & 67.89 & 76.50 & 72.19 & 25.02 & 33.76 & 29.39 & \multirow{2}{*}{63.05} & \multirow{2}{*}{50.15} & \multirow{2}{*}{56.60} \\
\hline & & & 49.29 & 54.77 & 52.01 & 30.00 & 35.45 & 32.73 & & & \\
\hline \multirow{2}{*}{3.} & \multirow{2}{*}{ Bitertanol } & \multirow{2}{*}{0.25} & 61.39 & 71.98 & 66.68 & 18.22 & 27.77 & 23.00 & \multirow{2}{*}{73.09} & \multirow{2}{*}{58.98} & \multirow{2}{*}{66.04} \\
\hline & & & 45.38 & 51.84 & 48.61 & 25.02 & 31.44 & 28.23 & & & \\
\hline \multirow{2}{*}{4.} & \multirow{2}{*}{ Tricyclazole } & \multirow{2}{*}{0.1} & 75.06 & 82.47 & 78.77 & 33.35 & 42.89 & 38.12 & \multirow{2}{*}{50.74} & \multirow{2}{*}{36.65} & \multirow{2}{*}{43.70} \\
\hline & & & 54.16 & 59.28 & 56.72 & 35.08 & 39.88 & 37.48 & & & \\
\hline \multirow{2}{*}{5.} & \multirow{2}{*}{ Iprobenphos } & & 77.87 & 86.05 & 81.96 & 37.81 & 49.33 & 43.57 & & & \\
\hline & & 0.25 & 56.33 & 61.81 & 59.07 & 37.85 & 44.69 & 41.27 & 44.16 & 27.14 & 35.65 \\
\hline 6 & & & 71.47 & 78.29 & 74.88 & 28.79 & 38.32 & 33.56 & & & \\
\hline 6. & Kast & 0.25 & 51.86 & 57.07 & 54.46 & 32.40 & 38.22 & 35.31 & 57.48 & .41 & 44 \\
\hline & & & 80.19 & 87.91 & 84.05 & 42.96 & 52.85 & 47.91 & & & \\
\hline 7. & Alternate sprays & - & 57.95 & 63.95 & 60.95 & 40.88 & 46.70 & 43.79 & 36.56 & 21.94 & 29.25 \\
\hline & & & 89.18 & 98.36 & 93.77 & 55.62 & 67.71 & 61.67 & & & \\
\hline 8. & Control & - & 68.18 & 82.61 & 75.40 & 48.36 & 55.64 & 52.00 & 17.86 & 0.00 & 8.93 \\
\hline & & & 73.63 & 81.95 & & 33.01 & 42.93 & & & & \\
\hline & Mean & & 60.91 & 68.10 & & 34.70 & 40.83 & & 51.25 & 36.60 & \\
\hline
\end{tabular}

\begin{tabular}{|c|c|c|c|c|c|c|}
\hline \multirow{2}{*}{ Source } & \multicolumn{3}{|c|}{ Incidence } & \multicolumn{3}{|c|}{ Intensity } \\
\hline & S.E. \pm & C.D. (0.05) & $\mathrm{CV}(\%)$ & S.E. \pm & C.D. (0.05) & CV (\%) \\
\hline Main plots & 0.37 & 1.20 & \multirow{3}{*}{12.74} & 0.28 & 0.93 & \multirow{3}{*}{12.11} \\
\hline Sub plots & 0.83 & 1.65 & & 1.55 & 4.70 & \\
\hline Main X Sub plots & 1.17 & 2.34 & & 1.56 & 4.49 & \\
\hline
\end{tabular}

Table 2: Influence of seed treatment, cultural practices and fungicides on management of brown spot of paddy (Three years' pooled results: 2009, 2010 and 2011)

\begin{tabular}{|c|c|c|c|c|c|c|c|c|c|c|c|}
\hline \multirow{4}{*}{$\begin{array}{l}\text { Sr. } \\
\text { No. }\end{array}$} & \multirow{4}{*}{ Fungicides } & \multirow{4}{*}{$\begin{array}{l}\text { Conc. } \\
(\%)\end{array}$} & \multicolumn{9}{|c|}{ Per cent brown spot } \\
\hline & & & \multirow{2}{*}{\multicolumn{3}{|c|}{$\begin{array}{c}\text { Incidence } \\
\text { Weighted pooled means }\end{array}$}} & \multicolumn{6}{|c|}{ Intensity } \\
\hline & & & & & & \multicolumn{3}{|c|}{ Pooled means } & \multicolumn{3}{|c|}{ Reduction (\%) } \\
\hline & & & M1 & M2 & Mean & M1 & M2 & Mean & M1 & M2 & Mean \\
\hline \multirow{2}{*}{1.} & \multirow{2}{*}{ Carbendazim } & \multirow[b]{2}{*}{0.1} & 47.60 & 58.62 & 53.11 & 21.50 & 31.41 & 26.46 & \multirow{2}{*}{60.70} & \multirow{2}{*}{42.59} & \multirow{2}{*}{51.64} \\
\hline & & & 41.09 & 46.84 & 48.37 & 30.79 & 36.98 & 33.88 & & & \\
\hline \multirow{2}{*}{2.} & \multirow{2}{*}{ Propiconazole } & \multirow{2}{*}{0.1} & 36.03 & 47.13 & 41.58 & 11.11 & 18.39 & 14.75 & \multirow{2}{*}{79.69} & \multirow{2}{*}{66.39} & \multirow{2}{*}{73.04} \\
\hline & & & 34.80 & 37.90 & 41.86 & 22.72 & 28.38 & 25.56 & & & \\
\hline \multirow{2}{*}{3.} & \multirow{2}{*}{ Bitertanol } & \multirow{2}{*}{0.25} & 40.27 & 51.36 & 45.81 & 15.10 & 23.22 & 19.16 & \multirow{2}{*}{72.39} & \multirow{2}{*}{57.57} & \multirow{2}{*}{64.98} \\
\hline & & & 36.94 & 40.02 & 44.39 & 25.71 & 31.20 & 28.46 & & & \\
\hline \multirow{2}{*}{4.} & \multirow{2}{*}{ Tricyclazole } & \multirow{2}{*}{0.1} & 45.04 & 55.13 & 50.09 & 19.93 & 29.29 & 24.61 & \multirow[b]{2}{*}{63.58} & \multirow[b]{2}{*}{46.47} & \multirow[b]{2}{*}{55.02} \\
\hline & & & 39.96 & 46.23 & 46.80 & 29.71 & 35.58 & 32.65 & & & \\
\hline & & & 55.36 & 65.24 & 60.30 & 27.43 & 36.96 & 32.19 & & & \\
\hline 5. & lprobenphos & 0.25 & 45.85 & 51.59 & 52.89 & 35.99 & 41.05 & 38.52 & 49.87 & 32.45 & 41.16 \\
\hline & & & 42.44 & 53.74 & 48.09 & 16.87 & 25.87 & 21.37 & 6917 & 5271 & \\
\hline 6. & Kasugamycin & 0.25 & 39.63 & 46.28 & 46.02 & 24.81 & 33.25 & 30.52 & 69.17 & 52.71 & 60.94 \\
\hline & & & 52.30 & 62.45 & 57.38 & 24.47 & 33.68 & 29.08 & & & \\
\hline 7. & Alternate sprays & - & 44.53 & 49.93 & 50.58 & 33.70 & 38.51 & 36.11 & 55.27 & 38.44 & 46.86 \\
\hline & & & 66.88 & 79.51 & 73.19 & 43.43 & 54.71 & 49.07 & & & \\
\hline 8. & Control & - & 50.67 & 58.35 & 59.66 & 45.46 & 51.47 & 48.47 & 20.61 & 0.00 & 10.30 \\
\hline & & & 48.24 & 59.15 & & 22.48 & 31.69 & & & & \\
\hline & Mean & & 41.60 & 47.98 & & 27.55 & 33.89 & & 58.91 & 42.08 & \\
\hline
\end{tabular}

\begin{tabular}{|c|c|c|c|c|c|c|}
\hline \multirow{2}{*}{ Source } & \multicolumn{3}{|c|}{ Incidence } & \multicolumn{3}{|c|}{ Intensity } \\
\cline { 2 - 3 } & S.E. \pm & C.D. (0.05) & CV (\%) & S.E. \pm & C.D. (0.05) & CV (\%) \\
\hline Main plots & 0.22 & 0.73 & \multirow{3}{*}{5.33} & 0.49 & 2.98 & \multirow{2}{*}{7.10} \\
\cline { 2 - 3 } \cline { 5 - 6 } & 0.42 & 0.83 & 0.38 & 0.76 & \\
\hline Sub plots & 1.35 & 3.91 & & 0.54 & 1.08 & \\
\hline
\end{tabular}

Note: The figures in the bold faces are arcsin values

M1: Seed treatment and cultural practices

M2: No seed treatment and cultural practices 
Table 3: Influence of integrated management of different diseases on yield of paddy (Three years' pooled results: 2009, 2010 and 2011)

\begin{tabular}{|c|c|c|c|c|c|c|c|c|c|c|c|c|c|c|}
\hline \multirow{4}{*}{$\begin{array}{l}\text { Sr. } \\
\text { No. }\end{array}$} & \multirow{4}{*}{ Fungicides } & \multirow{4}{*}{$\begin{array}{c}\text { Conc. } \\
(\%)\end{array}$} & \multicolumn{12}{|c|}{ Yield of } \\
\hline & & & \multicolumn{6}{|c|}{ Grains $\left(\mathbf{q}\right.$ ha $\left.^{-1}\right)$} & \multicolumn{6}{|c|}{ Straw $\left(q\right.$ ha $\left.^{-1}\right)$} \\
\hline & & & \multicolumn{3}{|c|}{ Weighted pooled means } & \multicolumn{3}{|c|}{ Increase over control (\%) } & \multicolumn{3}{|c|}{ Pooled means } & \multicolumn{3}{|c|}{ Increase over control (\%) } \\
\hline & & & M1 & M2 & Mean & M1 & M2 & Mean & M1 & M2 & Mean & M1 & M2 & Mean \\
\hline 1. & Carb & 0.1 & 33.61 & 29.85 & 31.73 & 90.14 & 68.86 & 79.50 & 37.37 & 33.27 & 35.32 & 79.98 & 60.22 & 70.10 \\
\hline 2. & Propi & 0.1 & 35.57 & 3 & 33.69 & 101.23 & 79.91 & 90 & 40.09 & 35.60 & 37.85 & 93.10 & 71.46 & 2.28 \\
\hline 3. & & 0.25 & 31.63 & 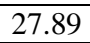 & 29.76 & 78.96 & 57.76 & 68.36 & 34.50 & 30.91 & 32.71 & 66.18 & 48.87 & 7.52 \\
\hline 4. & Tricy & 0.1 & 30.16 & 26.74 & 28.45 & 70.60 & 51.30 & 60.95 & 32.26 & 28.82 & 30.54 & 55.37 & 38.82 & 47.10 \\
\hline 5. & Iprobenphos & 0.25 & 26.70 & 23.67 & 25.19 & 51.07 & 33.92 & 42.49 & 28.41 & 25.05 & 26.73 & 36.84 & 20.66 & 28.75 \\
\hline 6. & Kasugamycin & 0.25 & 28.44 & 25.56 & 27.00 & 60.87 & 44.60 & 52.74 & 30.74 & 27.21 & 28.98 & 48.04 & 31.06 & 39.55 \\
\hline 7. & Alter & - & 27.26 & 24.32 & 25.79 & 54.22 & 37.57 & 45.90 & 29.00 & 25.97 & 27.49 & 39.69 & 25.08 & 32.38 \\
\hline 8. & & - & 22.70 & 17.68 & 20.19 & 28.43 & 0.00 & 14.21 & 24.75 & 20.76 & 22.75 & 19.18 & 0.00 & 9.59 \\
\hline & Mean & & 29.90 & 26.10 & & 66.94 & 46.74 & & 32.14 & 28.45 & & 54.80 & 37.02 & \\
\hline
\end{tabular}

\begin{tabular}{|c|c|c|c|c|c|c|}
\hline \multirow{2}{*}{ Source } & \multicolumn{3}{|c|}{ Grain yield } & \multicolumn{3}{c|}{ Straw yield } \\
\cline { 2 - 5 } & S.E. \pm & C.D. $(\mathbf{0 . 0 5})$ & CV (\%) & S.E. \pm & C.D. (0.05) & CV (\%) \\
\hline Main plots & 0.28 & 0.92 & \multirow{2}{*}{12.79} & 0.2 & 0.66 \\
\cline { 5 - 7 } \cline { 5 - 7 } & & 1.44 & 1.0 & 2.84 \\
\hline Main X Sub plots & 0.72 & 2.04 & 1.33 & 3.71 \\
\hline
\end{tabular}

Table 4: Total monetary returns, net profit and B: C ratio as influence by IDM in paddy (Three years' pooled results: 2009, 2010 and 2011)

\begin{tabular}{|c|c|c|c|c|c|c|c|c|c|c|c|}
\hline \multirow{2}{*}{$\begin{array}{l}\text { Tr. } \\
\text { No. }\end{array}$} & \multirow{2}{*}{$\begin{array}{l}\text { Name of } \\
\text { fungicides }\end{array}$} & \multirow{2}{*}{$\begin{array}{c}\text { Dose } \\
(\%)\end{array}$} & \multicolumn{3}{|c|}{$\begin{array}{l}\text { Total monetary returns } \\
\left(\text { Rs. ha }^{-1}\right)\end{array}$} & \multicolumn{3}{|c|}{$\begin{array}{c}\text { Total cost of } \\
\text { cultivation }\left(\text { Rs. }_{\text {ha }}{ }^{-1}\right)\end{array}$} & \multicolumn{3}{|c|}{ Net profit (Rs. ha-1) } \\
\hline & & & M1 & M2 & Mean & M1 & M2 & Mean & M1 & M2 & Mean \\
\hline 1. & C & 0.1 & 4078.71 & 400 & & 26373 & 20 & & 705.71 & & \\
\hline 2. & & & & & & 7143 & & & & & \\
\hline 3. & & & 0 & & & & & & & & \\
\hline 4. & & & 26 & & & 27829 & & 26 & 20 & & \\
\hline 5. & & & 9 & & & 28284 & & 27287 & 129 & & \\
\hline 6. & & & & & & 28137 & & 27140 & & .37 & 5.14 \\
\hline 7. & 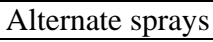 & 0.1 & 42925.02 & & & 26901 & 24907 & 25904 & 16024.02 & 11200.36 & 13612.19 \\
\hline 8. & & 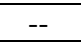 & 33966 & & 305 & 24461 & 22 & 23464 & 9505.92 & & 1.41 \\
\hline & Mean & & 46891.47 & 39730.66 & & 27785 & 25791 & & 19106.85 & 13940.04 & \\
\hline
\end{tabular}

\begin{tabular}{|c|c|c|c|c|c|c|}
\hline \multirow{2}{*}{ Source } & \multicolumn{3}{|c|}{ Total monetary returns } & \multicolumn{3}{c|}{ Net profit (Rs. ha $\left.^{-\mathbf{1}}\right)$} \\
\cline { 2 - 5 } & S.E. \pm & C.D. (0.05) & CV (\%) & S.E. \pm & C.D. (5\%) & CV (\%) \\
\hline Main plots & 455.53 & 2771.84 & \multirow{2}{*}{6.92} & 455.53 & 2771.84 & \multirow{2}{*}{18.14} \\
\hline Sub plots & 1223.74 & 3545.04 & 1223.74 & 3545.04 & \\
\hline Main X Sub plots & 1730.63 & 5013.44 & & 1730.63 & 5013.44 & \\
\hline
\end{tabular}

Table 5: Continued......

\begin{tabular}{|c|c|c|c|c|c|c|c|c|c|c|c|}
\hline \multirow{2}{*}{\begin{tabular}{|l|} 
Tr. \\
No.
\end{tabular}} & \multirow{2}{*}{$\begin{array}{c}\text { Name of } \\
\text { fungicides }\end{array}$} & \multirow{2}{*}{$\begin{array}{c}\text { Dose } \\
(\%)\end{array}$} & \multicolumn{3}{|c|}{ Additional MROC (Rs. ha' $\left.{ }^{-1}\right)$} & \multicolumn{3}{|c|}{ Per cent increase in MROC } & \multicolumn{3}{|c|}{ B:C ratio } \\
\hline & & & M1 & M2 & Mean & M1 & M2 & Mean & M1 & M2 & Mean \\
\hline 1. & Carbendazim & 0.1 & 26934.80 & 19264.49 & 23099.65 & 103.66 & 75.74 & 89.70 & 2.05 & 1.90 & 1.98 \\
\hline 2. & Propiconazole & 0.1 & 30904.94 & 22107.51 & 26506.23 & 119.46 & 86.59 & 103.02 & 2.14 & 1.96 & 2.05 \\
\hline 3. & Bitertanol & 0.25 & 24445.17 & 16826.75 & 20635.96 & 93.92 & 66.25 & 80.09 & 1.56 & 1.41 & 1.48 \\
\hline 4. & Tricyclazole & 0.1 & 20982.39 & 14079.09 & 17530.74 & 81.50 & 56.07 & 68.78 & 1.73 & 1.60 & 1.66 \\
\hline 5. & Iprobenphos & 0.25 & 14105.09 & 7814.31 & 10959.70 & 54.79 & 32.79 & 43.79 & 1.46 & 1.33 & 1.39 \\
\hline 6. & Kasugamycin & 0.2 & 18004.00 & 11638.46 & 14821.23 & 68.41 & 45.77 & 57.09 & 1.60 & 1.48 & 1.54 \\
\hline 7. & Alternate sprays & 0.1 & 15781.12 & 8963.46 & 12372.29 & 60.71 & 36.84 & 48.78 & 1.60 & 1.45 & 1.52 \\
\hline 8. & Control & -- & 6823.02 & 0.00 & 3411.51 & 25.96 & 0.00 & 12.98 & 1.39 & 1.21 & 1.30 \\
\hline & Mean & & 46891.47 & 19747.57 & 12586.76 & & 76.05 & 50.01 & & 1.69 & 1.54 \\
\hline
\end{tabular}

\begin{tabular}{|c|c|c|c|c|c|c|}
\hline \multirow{2}{*}{ Source } & \multicolumn{3}{|c|}{ Additional MROC } & \multicolumn{3}{c|}{ B : C ratio } \\
\cline { 2 - 3 } & S.E. \pm & C.D. $(\mathbf{0 . 0 5})$ & CV (\%) & S.E. \pm & C.D. (0.05) & CV (\%) \\
\hline Main plots & 455.53 & 2771.84 & \multirow{3}{*}{18.54} & 0.02 & 0.09 & \multirow{2}{*}{7.05} \\
\cline { 2 - 3 } \cline { 5 - 6 } & & 3545.04 & 0.05 & 0.13 & \\
\hline Sub plots & 1223.74 & 5013.44 & & 0.07 & 0.19 & \\
\hline
\end{tabular}

Note: M1 = Seed treatment and cultural practices

M2 $=$ No seed treatment and cultural practices

MROC $=$ Monetory returns over conctrol

Rates of fungicides

\begin{tabular}{|c|c|c|}
\hline Fungicides & Rs kg/L $\mathrm{L}^{-1}$ & Cost of Pseudomonas fluorescens: Rs. $40 \mathrm{ha}^{-1}$ \\
\hline Carbendazim & 560.0 & Cost of benomyl for seed treatmement: Rs. $124 \mathrm{ha}^{-1}$ \\
\hline Propiconazole & 1110.0 & RHA + rice straw (waste) with application: Rs. 1870 \\
\hline
\end{tabular}




\begin{tabular}{|c|c|c|}
\hline Bitertanol & 2160.0 & \\
\hline Tricyclazole & 1600.0 & Selling rates of produce \\
\hline Iprobenphos & 770.0 & Grains: Rs. 1100 to $1300 \mathrm{q}^{-1}$ \\
\hline Kasugamycin & 910.0 & Straw: Rs. $335 \mathrm{q}^{-1}$ \\
\hline Benomyl & 1030.0 & Cost of cultivation common to all treatments: Rs. 22467/- \\
\hline Mancozeb & 290.0 & \\
\hline Copper oxychloride & 430.0 & \\
\hline
\end{tabular}

\section{Conclusions}

The seed treatment with benomyl $(0.3 \%)$ and Pseudomonas fluorescens $(0.5 \%)$ to rice seeds along with cultural practices like soil application of rice husk ash (RHA) at sowing on raised beds @ $1 \mathrm{~kg} \mathrm{~m}^{-2}$ as well as soil application of rice straw (RS)@ 2 tones ha $^{-1}$ at transplanting followed by three sprays of propiconazole $(0.1 \%)$ or carbendazim $(0.1 \%)$ at 15 days interval starting first spray at disease appearance are recommended as a IDM module for effective management of sheath rot and brown spot diseases and increasing the grain and straw yields of paddy as well as monitory returns.

\section{References}

1. Datnoff Lawrence E. The economic potential of silicon for integrated management and sustainable rice production. Crop Protection. 2001; 20(1):43-48.

2. Anonymous. Standard Evaluation System for Rice (SES). Rice Science for a Better World-Rice Knowledge Bank. International Rice Research Institute, Philippines, 2002, 14.

3. Anonymous. India-October Crop Review and 2014 Winter Crop Prospects by Informa Economics Survey-Based Crop Reporting Service. Agri watch CROP-IND, 13-04, Oct 25:10-16, 2014.

4. Bag MK, Roychoudhury UK, Adhikari B. Evaluation of botanicals and biopesticides against sheath rot disease of rice. Journal of Crop and Weed. 2010; 6(2):82-83.

5. Dallagnol LJ, Rodrigues FA, Mielli MVB, Ma JF, Datnoff LE. Defective active silicon uptake affects some components of rice resistance to brown spot. Phytopathology. 2009; 99:116-121.

6. Das SR, Nayak Nivedita. Efficacy of fungicides in controlling sheath rot of rice in Orissa. Crop Research (Hisar). 1997; 14(3):497-500.

7. Datnoff Lawrence E, Kenneth W Seebold, Fernando J Correa. The use of silicon for integrated disease management: reducing fungicide applications and enhancing host plant resistance. Chapter 10 in Silicon in Agriculture. Studies in Plant Science. 2001; 8:171-184.

8. Datnoff LE, Raid RN, Snyder GH, Jones DB. Effect of calcium silicate on blast and brown spot intensities and yields of rice. Plant Dis. 1991; 75:729-732.

9. Datnoff LE, Rodrigues FA. The Role of Silicon in Suppressing Rice Diseases. APS net Features, 2005. Doi: 10.1094/APSnetFeature-2005-0205.

10. Datnoff LE, Snyder GH, Deren CW. Influence of silicon fertilizer grades on blast and brown spot development and on rice yields. Plant Disease. 1992; 76(10):1011-1013.

11. Dodan DS, Ram Singh, Sunder S. Efficacy of fungi toxicants against sheath rot of rice. Indian Journal of Mycology and Plant Pathology. 1996; 26(3):283-284.

12. Kaur P, Padmanadhan SY. Control of helminthosporium disease of rice with soil amendments. Curr. Sci. 1974; 43:78-79.

13. Lore JS, Thino TS, Hunjan MS, Gael RK. Performance of different fungicides against multiple diseases of rice. Indian Phytopathology. 2007; 60(3):296-301.
14. Lucas JA, Ramos B, Solano F, Montes J, Ojeda M, Megias, Gutierrez Manero FJ. Use of two PGPR strains in the integrated management of blast disease in rice (Oryza sativa) in Southern Spain. Field Crops Research. 2009; 114(3):404-410.

15. Nagrale Lalan, Sharma DT, Singh SK, Sharma KK, Sinha AP. A study on fungicides potential and incidence of sheath rot of rice caused by Sarocladium oryzae (Sawada). Journal of Applied and Natural Science. 2013; 5(1):24-29.

16. Prabhu AS. Control of the principal diseases of rice in dry lands. [Portuguese]. Informe Agropecuario (Belo Horizonte). 1989; 14(161):58-63.

17. Prathuangwong S, Chuaboon W, Chatnaparat T, Kladsuwan L, Shoorin M, Kasem S. Induction of disease and drought resistance in rice by Pseudomonas fluorescens SP007s. (Special issue on agricultural \& natural resources). Chiang Mai University Journal of Natural Sciences. 2012; 11(1):45-56.

18. Raja P, Saravanan R. Integrated Diseases Management in Paddy. A Report of College of Horticulture and Forestry, Central Agricultural University Pasighat, East Siang District, Arunachal Pradesh, 1993, 1-11.

19. Rodrigues FA, Benhamou N, Datnoff LE, Jones JB, Belanger RR. Ultrastructural and cytochemical aspects of silicon-mediated rice blast resistance. Phytopathology. 2003; 93:535-546.

20. Rodrigues Fabricio A, Datnoff Lawrence E. Silicon and rice disease management. Fitopatol. Bras, 2005, 30(5).

21. Rodrigues FA, McNally DJ, Datnoff LE, Jones JB, Labbe $\mathrm{C}$, Benhamou $\mathrm{N}$ et al. Silicon enhances the accumulation of diterpenoid phytoalexins in rice: A potential mechanism for blast resistance. Phytopathology. 2004; 94:177-183.

22. Seebold KW, Datnof JLE, Correa-Victoria FJ, Kucharek TA, Snyder GH. Effects of silicon and fungicides on the control of leaf and neck blast in upland rice. Plant Dis. 2004; 88:253-258.

23. Sunder S, Singh R, Dodan DS, Mehla DS. Effect of different nitrogen levels on brown spot (Drechslera oryzae) of rice and its management through host resistance and fungicides. Plant Disease Research (Ludhiana). 2005; 20(2):111-114.

24. Tirmali AM, Latake SB, Bendre NJ. Integrated management of blast disease of rice under rainfed conditions. Journal of Maharashtra Agricultural Universities. 2001; 26(2):192-193.

25. Venkateswarlu B, Venkateswarlu D. Efficacy of certain fungicides for the management of rice sheath rot Sarocladium oryzae (Sawada). Plant Protection Bulletin (Faridabad). 2004; 56(3/4):1-6.

26. Venkateswarlu Bolla, Venkateswarlu Dama, Chauhan HL. Evaluation of rice genotypes and fungicides against sheath rot of rice caused by Sarocladium oryzae Sawada. Journal of Research ANGRAU. 2004; 32(4):59-67. 